\title{
XLVI. On the new mountain barometer
}

\author{
Sir Henry C. Englefield Bart. F.R.S. and F.S.A.
}

To cite this article: Sir Henry C. Englefield Bart. F.R.S. and F.S.A. (1810) XLVI. On the new mountain barometer, Philosophical Magazine Series 1, 36:150, 241-243, DOI: 10.1080/14786441008563183

To link to this article: http://dx.doi.org/10.1080/14786441008563183

曲 Published online: 18 May 2009.

Submit your article to this journal $\pi$

LII Article views: 3

Q View related articles $\sqsubset$ 


\section{[ 241$]$}

XLVI. On the New Mountain Barometer. By Sir Hevry C. Englefield, Bart. F.R.S. and F.S.A.

\section{To $M r$. Tilloch.}

SrR, $T_{\text {h }}$ experience of three years having ascertained the convenience and utility of the mountain barometers, made on the principles of which a description, drawn up by me, was inserted in your Journal, (vol. $x \times x . p .46$,) $I$ am induced to address you again on the subject; both to inforn the public of some improvements made in their construction since my former letter, and to propose some mode of collecting, for general benefit, the observations made by individuals.

The improvement in the construction is principally in the cistern. It had been found that when exposed to great motion in an unfavourable position, which in long journeys is not easily avoided, the agitation of the mercury had several times cracked the tube towards the top, in a fissure scarcely perceptible to the eye, y'et sufficient to let in slowly a small portion of air. To remedy this inconvenience, the cistern has now a bottom of leather on which a screw presses in the usual mode, so as to force the mercury nearly to the top of the tube when packed for carriage. This screw is to be unscrewed as far as it can, when the harometer is prepared for use; and the leather bag is so adjusted, that there is no reason to fear that the capacity of the cistern thus'unscrewed for use, will ever be sensibly different from itself at different times. It may be just mentioned, that when the barometer is carried by a careful person, it is by no means necessary to serew up the bag between every, station; as, when unscrewed, the instrument is in precisely the same state that it always was, in those of the first construction*.

Mr. Jones, at the desire of several gentlemen, has endeavoured to add a gauge point and adjustment to keep the mercury in the cistern ever to the same height, as in other mountain barometers, but such addition has been found in practice productive of more inconvenience than advantage. He now, therefore, measures the content of every tube separately, and engraves on the mounting the correction to be made to the results, as stated in the former paper; and by this method it is presumed that all errors from the want of a gauge point must be prevemed. Mr.'Jones has

* The screw which frees the cistern for use, is protected by an outer cap from being spoiled by idle curiosity, or injured by a lintw, which often happe:sd to those barometers where this screw was unprotected.

Vol. 36. No. 150. Oct. 1810. 
now sold above 150 barometers of this construction. Of these, it cannot be doubted that by far the greater part has been purchased by gentlemen both able and desitous to use them for the parpose of measuring heights ; and I know that a great number of valuable observations have heen made with them in different parts of our islands. While, however, these observations remain in the hands of the observers, the public is little benefited by them; and 1 doubt rot that if it were generally known that a deposit for them was provided, all those gentlemen who have made observations of altitudes with these, or any other gond mountain barometers, would readily scnd their observations, and contribute their part to the common stock of valuable information which would be deduced from the publication either of the observations themselves or the results of them.

For this purpose Mr. Jones, late of Mount-strect, now of Kentun-stret, Brunswick-square, the same ingenious artist who made these barometers at first under my inspection, has kindly consented, at my request, to receive and arrainge all such observations as may be trainsmitted to him (post paid or franked) by the gentlemen who have made them; and I shall be harpy not only to assist him in computing them, but will readily superintend the publacation of them, either in the literary joumals, or in a separate work, as may in process of time appear the most eligible. It seems the minst desirable that the names of the observers should be published with their observations, as giving the stamp of authenticity to them: this, however, will be done, or omitted, as the several contributors may wish.

As it is to be hoped that the communications may be numerous, it will materially diminish the labours of arrangement, if a general form be adopied in sending the observations; and it is hoped that the specimen here annexed will be found convenient to the observers themselves, as well as to thuse whose province it may be to collect them.

Extensive geological observations would be in this case out of their place; yet it might be useful, and productive of little additional labour or trouble, if the soil of the spot where each observation was made could, if possible, be specified. Another observation ncarly connected with that of the barometer and thermometer for altiudes, is the temperature of the waters at or near the places of observation. Wells of 40 or 50 feet deep are, for this purpose, more to be depended on than springs, which often run at so small a depth below the surface of the ground as to be much affected by the beat and cold of summer and winter. 
It will, bowever, be best to make observations as often as possible both on the one and the other, as it has been ascertained, both by Mr. Cavendish and the late Dr. Hunter, that the temperature of the waters at any given place is a most accurate measure of its mean beat; a determination of which is not only an object of considerable curiosity in itself, but of very great consequence in an agricultural point of view.

The annexed form for registering the observations scarcely requires an explanation. The first column is for numbering the observations, which extremely facilitates the reference 10 them. The succeeding columns are fully explained by their titles. The last, called Results, is added, in order that those persons who choose it may place in one view the observations, and the altitudes deduced from them. Printed sheets in this form, ready for use, may be had of Mr. Jones. The back of each page is left blank, for the convenience of inserting any other nutes or observations.

$$
\text { I am, sir, }
$$

Your humble servant,

H. C. ENGLefintd.

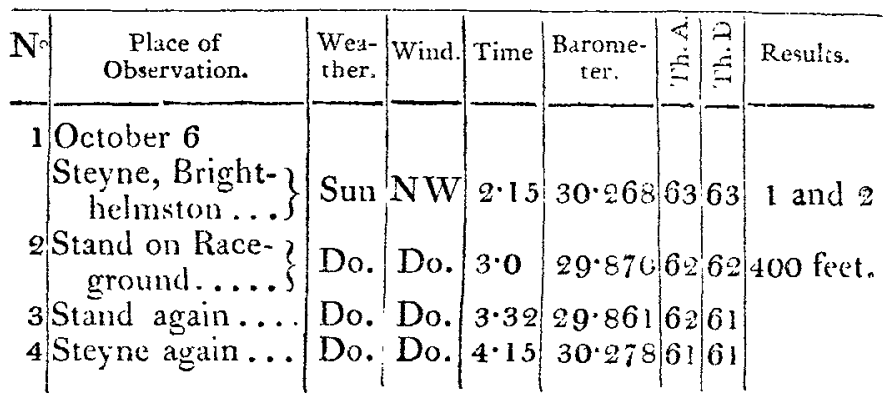

XLVIT. On the Land Winds of Coromandel, and their Causes. By William Roxbukgh, M.D.*

$T_{\text {He land winds on the coast of Coromandel are those }}$ hot winds which blow at a particular season of the year, and hour of the day, from the western hills, commonly called the Ghauts, towards the Bay of Bengal. In the more inland countries, as above the Ghauts, they are not

* From Transactions of the Medical Society of London, vol. i. part I. just published.

$$
\mathrm{Q}^{2} \quad \text { confined }
$$

